\title{
HLA class II antigens (DR, DQ loci) and peripheral arthritis in ankylosing spondylitis
}

\author{
R SANMARTÍ, ${ }^{1}$ M G ERCILLA ${ }^{2}$ M A BRANCÓS, ${ }^{1}$ M C CID ${ }^{2}$ \\ A COLLADO, AND J ROTÉS-QUEROL ${ }^{1}$ \\ From the Departments of ${ }^{I}$ Rheumatology and ${ }^{2}$ Immunology, Hospital Clínico y Provincial Barcelona, Spain
}

SUMMARY Fifty one patients with ankylosing spondylitis (AS) were typed for HLA-A, B, C, $\mathrm{DR}$, and $\mathrm{DQ}$ antigens. The antigen frequencies were compared with those of a normal population and with a B27 positive control group. All but one of the patients with AS were HLAB27 positive. A positive linkage disequilibrium between $\mathrm{Cw} 1, \mathrm{Cw} 2, \mathrm{DR} 1$, and the B27 antigen was observed. Patients with AS showed a significant increase in DQw2 antigen compared with the B27 positive control group. No differences in antigenic frequencies were observed in patients having peripheral arthritis and patients with only axial involvement. Seven out of nine patients $\mathbf{( 7 8 \% )}$ with an erosive peripheral arthritis were DR7 positive, suggesting that DR7 or genes closely linked could be related with a more aggressive peripheral joint involvement in patients with AS.

Key words: major histocompatibility complex.

Since 1973 ankylosing spondylitis (AS) has been known to be very strongly associated with the HLAB27 antigen, ${ }^{12}$ but no convincing relationships between this disease and other HLA class I or class II antigens have been demonstrated. ${ }^{34}$

Although axial arthritis with invariable sacroiliac involvement characterises the disease, many patients have involvement of the peripheral joints at some time during the course of their disease..$^{56}$ The occurrence of peripheral arthritis in patients with AS could be related to environmental factors, absent in patients with only axial involvement, or may reflect differences in additional genetic determinants which may or may not be linked to the B27 antigen. ${ }^{7}$ To analyse the genetic susceptibility to developing peripheral arthritis in AS a few studies were carried out, ${ }^{489}$ but the results are discordant, probably because different methodological criteria were used. This study reports the class I and class II antigen frequencies in 51 spondylitic patients, 25 of them with peripheral involvement and a subset of these patients having an erosive peripheral arthritis.

\section{Patients and methods}

Fifty one patients (48 male, three female) fulfilling

Accepted for publication 16 February 1987

Correspondence to Dr R Sanmartí, Servicio de Reumatología, Hospital Clínico y Provincial, C/Villarroel 170, 08036 Barcelona, Spain. the New York criteria for definite $\mathrm{AS}^{10}$ were studied. The mean duration of the disease was 17 years (range 2-36). According to the presence of peripheral arthropathy patients were subdivided into two groups: group I consisted of 25 patients with axial involvement and peripheral arthritis; their symptoms began between the ages of 12 and 39 years (mean 24.1) and had a follow up period of between two and 27 years (mean 14.4). Polyarticular involvement was present in 12 patients and pauciarticular in 13. In five patients the onset of AS was before the age of 16 (juvenile AS). Peripheral arthritis was the first symptom in 14 patients. Erosive peripheral arthritis was present in nine patients. Group II was made up of 26 patients that had only axial involvement with an evolution between 10 and 36 years (mean 19.4). In these patients the disease began between the ages of 17 and 39 years (mean 25.5). Ćlinical features of both groups are shown in Table 1.

Patients with psoriasis, Reiter's syndrome, or inflammatory bowel disease were excluded.

Peripheral joint involvement was established if patients had had symptoms (pain, stiffness) and signs (swelling or effusion, restriction of movements) in one or more joints for more than six weeks observed by a physician. Patients with arthralgias without inflammation were not included. The hip and shoulders were considered to be axial joints. 
Table 1 Characteristics of 51 patients with ankylosing spondylitis

\begin{tabular}{|c|c|c|c|c|}
\hline & \multicolumn{2}{|c|}{$\begin{array}{l}\text { Group I: } \\
\text { peripheral } \\
\text { arthritis } \\
(n=25)\end{array}$} & \multicolumn{2}{|c|}{$\begin{array}{l}\text { Group II: } \\
\text { axial } \\
\text { involvement } \\
\text { only }(n=26)\end{array}$} \\
\hline & No & $\%$ & No & $\%$ \\
\hline Women & 1 & 4 & 2 & $7 \cdot 7$ \\
\hline Uveitis & 3 & 12 & 4 & $15 \cdot 4$ \\
\hline Amyloidosis & 3 & 12 & 2 & $7 \cdot 7$ \\
\hline \multicolumn{5}{|l|}{ Involved joints } \\
\hline Hip & 8 & 32 & 8 & $30 \cdot 8$ \\
\hline Shoulder & 4 & 16 & 2 & $7 \cdot 7$ \\
\hline Knee & 21 & 84 & - & - \\
\hline Ankle & 17 & 68 & - & - \\
\hline MTP* & 12 & 48 & - & - \\
\hline Elbow & 3 & 12 & - & - \\
\hline Wrist & 7 & 28 & - & - \\
\hline PIP-MCP* & 7 & 28 & - & - \\
\hline Enthesopathy (calcaneitis) & 7 & 28 & 1 & $3 \cdot 8$ \\
\hline
\end{tabular}

${ }^{*} \mathrm{MTP}=$ metatarsophalangeal; $\quad \mathrm{PIP}=$ proximal interphalangeal; $\mathrm{MCP}=$ metacarpophalangeal.

HLA TYPING

HLA-A, B, and C typing was carried out by the complement dependent microlymphocytotoxicity test ${ }^{11}$ with sera recognising 63 specificities defined in the 9th Histocompatibility Workshop. ${ }^{12}$ HLA-DR and DQ were typed by complement dependent microlymphocytotoxicity on nylon wool enriched mononuclear cell populations. ${ }^{13}$ Antisera used to type HLA-A, B, C, DR, and DQ antigens were either obtained locally or were gifts from other laboratories.

\section{CONTROL GROUPS}

Two control groups were used in the study. The first consisted of 200 unrelated people as representative of the general population and the second group included 50 unrelated people selected from the general population having the HLA-B27 antigen. Both control groups and patients were ethnically comparable and living in the same area.

STATISTICAL METHODS

Statistical analysis was by the $\chi^{2}$ test with Yates's correction when necessary.

\section{Results}

H L A TYPING IN AS

All patients but one were HLA-B27 positive (98\%). Homozygosity for B27 could not be excluded in five patients. The HLA antigens Cw1, Cw2, and DR1 were significantly increased in patients with AS compared with the random population $(p<0.001)$ but not with the B27 positive control group. This finding indicates a linkage disequilibrium between these three antigens and B27 (Table 2). The prevalence of the DR7 antigen in patients with AS $\stackrel{\overrightarrow{9}}{+}$ was similar to that in the random population $(35.2 \%$ 을 versus $36 \%$ ) but more frequent than in the B27 흘 control group $(20 \%)$, thus the increase of DR7 in $\frac{5}{7}$ patients with AS involves a different pattern of $\stackrel{\varnothing}{\varrho}$ association than in B27 positive controls. A similar pattern was observed with the DQw2 antigen, which was more prevalent in spondylitic patients and in the general population than in the B27 control group $(\mathrm{p}<0.001)$. Hence a negative linkage disequilibrium between DQw2 and the B27 antigen was observed. This negative linkage disequilibrium between DR7, and mainly DQw2 and HLA-B27 was not observed in patients with AS despite the presence of the B27 antigen in all but one of the patients.

HLA AND PERIPHERAL ARTHRITIS IN AS

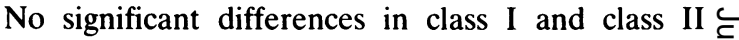
antigen distribution were observed between patients having only axial involvement (group II) and those $\vec{\bullet}$ with peripheral arthritis (group I) (Table 3). No $\stackrel{\infty}{-}$ differences were found either when we analysed separately patients with pauciarticular and polyarticular involvement (data not shown). Of the nine patients with erosive peripheral arthritis, seven $(77.7 \%)$ had the DR7 antigen compared with only two $(12 \cdot 5 \%)$ of the 16 patients with non-erosive peripheral arthritis $(\mathrm{p}<0.005)$.

Table $2 H L A$ class $I(A, B, C$ loci) and class II $(D R, D Q$ loci) antigens in $A S$

\begin{tabular}{|c|c|c|c|c|c|c|}
\hline \multirow[t]{3}{*}{$\begin{array}{l}H L A \\
\text { antigen }\end{array}$} & \multicolumn{2}{|c|}{$\begin{array}{l}A S \\
(n=51)\end{array}$} & \multicolumn{2}{|c|}{$\begin{array}{l}\text { Random } \\
\text { controls } \\
(n=200)\end{array}$} & \multicolumn{2}{|c|}{$\begin{array}{l}\text { HLA-B27 } \\
\text { controls } \\
(n=50)\end{array}$} \\
\hline & \multirow[t]{2}{*}{ No } & \multirow[t]{2}{*}{$\%$} & & & & \\
\hline & & & No & $\%$ & No & $\%$ \\
\hline B27 & 50 & 98 & 10 & 5 & 50 & 100 \\
\hline Cw1 & $27^{*}$ & $52 \cdot 9$ & 10 & 5 & 22 & 44 윽 \\
\hline $\mathrm{Cw} 2$ & $20^{*}$ & $39 \cdot 2$ & 10 & 5 & 19 & 38 \\
\hline DR1 & $23^{*}$ & 45 & 39 & $19 \cdot 5$ & 19 & 38 \\
\hline DR2 & 3 & $5 \cdot 8$ & 34 & 17 & 6 & 12 \\
\hline DR3 & 14 & $27 \cdot 4$ & 48 & 24 & 12 & 24 \\
\hline DR4 & 8 & $15 \cdot 6$ & 40 & 20 & 12 & 24 \\
\hline DR5 & 15 & $29 \cdot 4$ & 59 & $29 \cdot 5$ & 11 & 22 \\
\hline DR6 & 3 & $5 \cdot 8$ & 19 & $9 \cdot 5$ & 4 & 8 \\
\hline DR7 & 18 & 35.2 & 72 & 36 & $10^{* *}$ & 206 \\
\hline DR8-9-10 & 8 & $15 \cdot 6$ & 10 & 5 & 4 & \\
\hline DQw1 & 26 & $50 \cdot 9$ & 111 & $55 \cdot 5$ & 32 & 64 \\
\hline DQw2 & $24^{* * *}$ & 47 & 98 & 49 & 8 & $16^{2}$ \\
\hline DQw3 & 17 & $33 \cdot 3$ & 89 & $44 \cdot 5$ & 24 & 40 \\
\hline
\end{tabular}

Values of DR and DQ antigen frequencies and those class antigens showing changes are included.

${ }^{*} \mathrm{p}<0.001$ and ${ }^{* *} \mathrm{p}<0.05$ both compared with the random controls $;$ ${ }^{* * *} \mathrm{p}<0.001$ compared with the B27 control group. 
Table 3 HLA class II antigens and peripheral arthritis in $A S$

\begin{tabular}{|c|c|c|c|c|}
\hline \multirow[t]{3}{*}{ Antigen } & \multirow{2}{*}{\multicolumn{2}{|c|}{$\begin{array}{l}\text { Group I: } \\
\text { peripheral } \\
\text { arthritis } \\
(n=25)\end{array}$}} & \multicolumn{2}{|c|}{$\begin{array}{l}\text { Group II: } \\
\text { axial disease } \\
\text { only }(n=26)\end{array}$} \\
\hline & & & \multirow{2}{*}{ No } & \multirow{2}{*}{$\%$} \\
\hline & $N o$ & $\%$ & & \\
\hline DR1 & 12 & 48 & 11 & $42 \cdot 3$ \\
\hline DR2 & 0 & 0 & 3 & $11 \cdot 5$ \\
\hline DR3 & 7 & 28 & 7 & $26 \cdot 9$ \\
\hline DR4 & 2 & 8 & 6 & 23 \\
\hline DR5 & 7 & 28 & 8 & $30 \cdot 7$ \\
\hline DR6 & 2 & 8 & 1 & $3 \cdot 8$ \\
\hline DR7 & 9 & 36 & 9 & $34 \cdot 6$ \\
\hline DR8-9-10 & 4 & 16 & 4 & $15 \cdot 3$ \\
\hline DQw1 & 15 & 60 & 11 & $42 \cdot 3$ \\
\hline DQw2 & 11 & 44 & 13 & 50 \\
\hline DQw3 & 7 & 28 & 10 & $38 \cdot 4$ \\
\hline
\end{tabular}

No differences were seen when class I antigens were analysed.

\section{Discussion}

Because of the close link between HLA-B27 and AS little attention has been paid to the class II antigens in this illness. Almost all studies have shown that the prevalence of the D or DR loci in AS is similar to that in the normal population. ${ }^{3} 414-17$

When we compared the antigen frequencies of patients with AS (all but one carrying the B27 antigen) with those of a B27 positive control population a positive linkage disequilibrium between DR1 and B27 positive antigens was observed, which would explain the increase in DR1 in AS observed by other groups, ${ }^{414}$ and suggests that this antigen does not have any role in the disease susceptibility. We also observed a negative linkage disequilibrium between DR7 and B27, which has already been reported. ${ }^{8} 12$ In contrast, the frequency of DR7 in our patients is similar to that of the general population but markedly greater than that of the B27 positive control group.

In our study DQw2 was increased in patients with AS compared with the B27 positive control group $(47 \% \vee 16 \%)$. We are not aware of any previous analysis of the DQ locus in AS. The existence of a strong negative linkage disequilibrium between B27 and DQw2 was reported during the 9th Histocompatibility Workshop. ${ }^{12}$ This unexpected increase of DQw2 (which can be due only in part to the greater frequency of DR7 in our patients, an antigen linked to DQw2) could point to the existence of other genetic markers or the presence of different haplotypes in spondylitic patients and healthy people having the B27 antigen. This latter hypothesis could not be confirmed by Lochead et al, ${ }^{18}$ but class II antigens were not studied in their report.

Møller et al are of the opinion that AS is a multigenic syndrome in which the B27 antigen is not the only genetic factor involved, even though it is the main one. ${ }^{719}$ The expression of these genes in addition to B27 could cause modifications of the clinical course of the disease. Following on from this theory the possibility that patients with AS having peripheral joint involvement would be genetically different from those having only axial involvement has recently been suggested, though results have shown discrepancies. ${ }^{4} 89$

To test whether a genetic susceptibility to develop peripheral arthritis in the course of AS is HLA related we selected patients with peripheral arthritis, most of whom were severely affected. The group with axial involvement only had been followed up for more than 10 years to make sure that they were not prone to develop peripheral arthritis, as peripheral involvement occurs frequently in the first 10 years of the disease. ${ }^{20}$

We have not found differences in HLA antigenic frequencies between the groups of patients with or without peripheral arthritis. The antigens Cw1, $\mathrm{Cw} 2$, and DR1 were increased in both groups because of the linkage disequilibrium with HLAB27.

An increased frequency of DR4 antigen was found by Miehle et al in AS patients with 'pure peripheral arthritis' involving only wrist, ankle, toe, and finger joints. ${ }^{9}$ Three patients included in our study had this pattern of joint involvement and none of them carried the DR4 antigen.

A similar DR7 antigen frequency was found in patients with peripheral arthropathy and those having only axial disease. In the group with peripheral involvement there was a relation between the severity of the peripheral arthritis and the DR7 antigen: seven out of the nine patients with an erosive peripheral arthritis were DR7 positive $(77 \cdot 7 \%)$. Aaron et al found an increase in the DR7 antigen in AS patients with peripheral arthritis, though the features of arthritis were not reported. ${ }^{8}$ On the other hand, an increase of DR7 in psoriatic arthritis is well recorded, ${ }^{342}$ but none of our patients had psoriasis. Thus the DR7 antigen, or genes closely linked, could be related to the development of a more aggressive peripheral arthritis in AS. Further studies are necessary to confirm this.

The HLA-B27 antigen is the most important marker of AS. In view of our results we cannot exclude the possibility that other genes in the major histocompatibility complex may contribute to the susceptibility and clinical heterogeneity of the disease. 
The authors wish to thank Ms María Luisa Vidal and Ms Pilar Ortega for technical assistance and Ms Carol de Merieux for translation suggestions. This study was supported by a grant from the Hospital Clínic de Barcelona.

\section{References}

1 Brewerton D A, Caffrey M, Hart F D, James D C O, Nicholls A, Sturrock R D. Ankylosing spondylitis and HLA B27. Lancet 1973; i: 904-7.

2 Schlosstein L, Terasaki P I, Bluestone R, et al. High association of an HL-A antigen, W 27 with ankylosing spondylitis. $N$ Engl $J$ Med 1973; 288: 704-6.

3 Espinoza L R, Vasey F B, Gaylord S W, et al. Histocompatibility typing in the seronegative spondyloarthropathies: a survey. Semin Arthritis Rheum 1982; 11: 375-81.

4 Armstrong R D, Panayi G S, Welsh K I. Histocompatibility antigens in psoriasis, psoriatic arthropathy, and ankylosing spondylitis. Ann Rheum Dis 1983; 42: 142-6.

5 Resnick D. Patterns of peripheral joint disease in ankylosing spondylitis. Radiology 1974; 110: 523-32.

6 Ginsburg W W, Cohen M D. Peripheral arthritis in ankylosing spondylitis: a review of 209 patients followed up for more than 20 years. Mayo Clin Proc 1983; 58: 593-6.

7 Møller P, Berg K. Seronegative arthropathy and associated diseases-a multigenic syndrome? Br J Rheumatol 1983; 22 (suppl 2): 5-11.

8 Aaron S, Miller M L, Howard J, et al. Complementation with HLA-A and HLA-D locus alleles in ankylosing spondylitis with peripheral arthritis. J Rheumatol 1985; 12: 553-7.

9 Miehle W, Schattenkirchner M, Albert D, Bunge M. HLADR4 in ankylosing spondylitis with different patterns of joint involvement. Ann Rheum Dis 1985; 44: 39-44.

10 Calin A. Ankylosing spondylitis. In: Kelley W N, Harris E D
Jr, Ruddy S, Sledge C B, eds. Textbook of rheumatology Philadelphia: Saunders, 1982: 1017-30.

11 Mittal K K, Mickey M R, Singal D P, Terasaki P I. Serotypin $\vec{c}$ for homotransplantation. XVIII. Refinement of microdople lymphocyte cytotoxicity test. Transplantation 1968; 6: 913-27.O

12 Albert E D, Bart M P, Mayr W R, eds. Histocompatibilit. testing 1984. Berlin: Springer, 1984.

13 Lowry R, Goguen J, Carpenter C B. Improved B cell typing fo HLA-DR using nylon wool column enriched B lymphocyt preparations. Tissue Antigens 1979; 14: 325-30.

14 Sachs J, Sterioff S, Robinette M, et al. Ankylosing spondyliti? and the major histocompatibility system. Tissue Antigens $1975 \vec{\circ}$ 5: $120-7$.

15 Dejelo C L, Braun W E, Khan M A, Clough J D. HLA DR antigens and ankylosing spondylitis. Transplant Proc 1978; 10N 971-2.

16 Gaucher A, Raffoux C, Netter P, Faure G, Pourel J, Streiff Fö HLA DRw dans la spondyloarthrite ankylosante. Rev Rhum Mal Osteoartic 1978; 45: 335-8.

17 Kemple K, Gatti R A, Leibold W, Klinenberg J, Bluestone R: HLA D locus typing in ankylosing spondylitis and Reiter syndrome. Arthritis Rheum 1979; 22: 371-5.

18 Lochead J A, Chalmers I M, Marshall W H. HLA-B2? haplotypes in family studies of ankylosing spondylitis. Arthritis. Rheum 1983; 26: 1011-6.

19 Møller P, Vinje O, Kåss E, Berg K. The distribution of clinica findings in Bechterew's syndrome (ankylosing spondylitis) suggests distinct genetic subgroups. Clin Genet 1982; 22: 151-9

20 Carette S, Graham D, Little H, Rubenstein J, Rosen P. Th@ natural disease course of ankylosing spondylitis. Arthritis Rheum 1983; 26: 186-90.

21 Seignalet J, Sany J, Lapcusk H. Probable relation betwee HLA-DR7 and peripheral psoriatic arthritis. Presse Med 1983롱 12: $1173-4$. 